\title{
"Betwixt and Between": Physical Anthropology in Bulgaria and Serbia until the End of the First World War
}

\author{
Christian Promitzer
}

Bulgaria entered the First World War on the side of the Central Powers in September 1915. At the time, few in the German Reich had profound knowledge of its new ally. The German majority cultivated vague impressions of a possibly wild and romantic, but definitely backward, petty kingdom somewhere on the eastern fringes of Europe. The better informed also knew that the monarch was of German descent, and that the First Balkan War of 1912-1913, in which the Bulgarian army was a decisive party, had been a rehearsal to the ongoing European war with respect to conduct and weapons. Experts on Bulgaria-among them anthropologists and ethnologists-quickly perceived an opportunity to gain publicity by servicing the demand for information.

In 1917, Johann Baptist Loritz (1891-1965) published a short book, Unser Verbündeter Bulgarien [Our Ally Bulgaria], dedicating several pages of its lengthy chapter on the Bulgarian people to anthropological origins. Like the Serbs and Croats, Bulgarians were linguistically South Slavs, but Loritz stressed their divergent racial makeup-especially opportune now that Serbia was an enemy of the Reich. Bulgarians, he claimed, differed somatically from other South Slavs. Serbs were taller, with lighter hair and eyes, while Bulgarians were more compact, but with a reduced incidence of brachycephaly (round heads). The Balkan Peninsula's pre-Slavic Illyrian population had left only minor traces among the Bulgarians, compared to other South Slavs. Instead, the Bulgarian's ancestors were non-Slavic "proto-Bulgarians" from the Volga basin who had settled the country in the sixth and seventh centuries. Loritz contended that his own anthropological investigations had shown that the Bulgarians were not of Finnish origin, as was commonly held by scholars in Bulgaria, but were descendants of the ancient population of 
Asia Minor and nomadic peoples of North Africa. ${ }^{1}$ How did Loritz acquire this sophistication about the Bulgarian people? And what was the relevance of their appearance to the war?

Loritz was the deputy secretary of Munich's German-Bulgarian Society, founded to strengthen bonds between the allies. ${ }^{2} \mathrm{He}$ owed his expertise to an excursion in the summer of 1913, where he undertook anthropological examinations of about fifty skulls; his findings were published in his doctoral dissertation in 1915. ${ }^{3}$ While in Bulgaria, he also examined Macedonian refugees from the Balkan wars. In the winter term of 1914, he examined circa one hundred Bulgarian students at the University of Munich, ${ }^{4}$ where he was a student of Johannes Ranke (1836-1916) and Ferdinand Birkner (1868-1944). ${ }^{5}$ The firstever professor of anthropology in Germany and author of Der Mensch, an influential work of the 1880 s, Ranke had become something of a monument. The considerably younger Birkner served as associate professor of anthropology and custodian of the Bavarian State Prehistoric Collection as well as founder and chairman of the German-Bulgarian Society.

Obviously, Loritz's tendentious depiction of the origins and bodily particularities of the Bulgarian people was not a product of his thirst for knowledge alone. Its aim was also to provide fodder for anthropological propaganda: Serbian-Bulgarian affinities-be they somatic, linguistic, or ethnographic-had become inappropriate after Bulgaria took part in the conquest of Serbia by the Central Powers in 1915. But animosities between Serbian and Bulgarian national elites dated from the late nineteenth century, revolving around the ethnic affiliation of the Slavic population of Macedonia, then an Ottoman province. In the First Balkan War, Bulgaria had joined Serbia and Greece in attacking the Ottoman Empire in order to seize its Balkan provinces, but soon thereafter felt cheated of its share of the Macedonian spoils.

1 Johann Baptist Loritz, Unser Verbündeter Bulgarien (Regensburg: Friedrich Pustet, 1917), 61-66.

2 Цветана Тодорова [Cvetana Todorova] and Елена Стателова [Elena Statelova], “Към началната история на Германско-българското дуржество (1916-1918)" [On the first years of the German-Bulgarian Society (1916-1918)], in Българско-германски отношения и вързки: Изследвания и материали [Bulgarian-German relations and connections: Studies and materials], vol. 2, ed. Българска Академия на науките, Институт за история [Bulgarian Academy of Sciences, Institute for History] (Sofia: БАН [Bulgarian Academy of Sciences], 1979), 165.

3 Johann Baptist Loritz, Anthropologische Untersuchungen an bulgarischen Schädeln aus alter und neuer Zeit (Munich: J. Fuller, 1915).

4 Idem, "Über die Herkunft des südbulgarischen Dolichocephalus," Korrespondenz-Blatt der Deutschen Gesellschaft für Anthropologie, Ethnologie und Urgeschichte 46, nos. 5-8 (1915): 21.

5 Idem, Anthropologische Untersuchungen, 8, 157. 
In 1913, Bulgaria declared war on Serbia and Greece, losing its Second Balkan War in a matter of weeks. This defeat prompted Bulgaria to enter World War I as an ally of the Central Powers two years later.

Birkner delivered a lecture on "Bulgaria in Prehistoric Times" at the German-Bulgarian Society in late 1916. ${ }^{6}$ In May 1917, he published his views on the anthropological properties of the Bulgarians in the Deutsche Balkanzeitung, a Sofia-based paper responsible for spreading propaganda for the Central Powers in southeastern Europe. ${ }^{7}$ Due to the manifold waves of migration that had rolled over Bulgaria throughout history, Birkner wrote, its inhabitants' "somatic peculiarities do not show too much homogeneity." However, he found the data sufficient to justify according the prehistoric Balkan population a greater role in shaping the modern Bulgarian than had Loritz. $^{8}$

Georg Buschan's (1862-1943) 1917 booklet is also worthy of mention: He awarded the Bulgarians first prize among the peoples of the Balkans for their "bravery, patriotism, intelligence, and aspiration to higher things." Buschan conceded that cohabitation with Slavic peoples since their arrival in the seventh century had tainted Bulgarian purity, but "by the power of heredity, an array of characteristics distinct from the Slavic type have preserved themselves now and then among the population." ${ }^{10}$ In his view, Finns, Hungarians, and Turks-allies or potential allies of the Reich-were the closest relatives of the original Bulgarians. ${ }^{11}$ Like Loritz, Buschan stressed that Bulgarians differed somatically from Serbs, Romanians, and Greeks. ${ }^{12}$ He noted the frequent occurrence of central Asian traits (which he considered to be such phenomena as brachycephaly and the epicanthal fold) among the population of northern Bulgaria, whereas, in southern Bulgaria, dolichocephaly (long-headedness) was more common. Whereas Loritz had derived southern Bulgarians' long heads from ancient Mediterranean peoples and North African nomads,

6 Helmut W. Schaller, "Wissenschaftliche Sammelbände zu Bulgarien in Deutschland im 20. Jahrhundert," Bulgarian Historical Review 34, nos. 1-2 (2006): 43; Ferdinand Birkner, "Die Vorgeschichte Bulgariens," Korrespondenz-Blatt der Deutschen Gesellschaft für Anthropologie, Ethnologie und Urgeschichte 47, nos. 7-9 (1916): 41-47.

7 Todorova and Statelova, "On the First Years of the German-Bulgarian Society," 190-191.

8 Ferdinand Birkner, "Die anthropologische Erforschung Bulgariens," Deutsche Balkanzeitung, May 15, 1917.

9 Georg Buschan, Die Bulgaren: Herkunft und Geschichte, Eigenschaften, Volksglauben, Sitten und Gebräuche (Stuttgart: Strecker und Schröder, 1917), 1.

10 lbid., 4.

11 Ibid., 5, 10.

12 Ibid., 19. 
Buschan saw a connection to northern Europe, as he believed the Balkan mountain range had saved southern Bulgaria from being overrun by Asian Fremdvölker [foreign peoples]. ${ }^{13}$

As a leading figure in the popularization of ethnology in Germany, Buschan could rely on a rich literature on contemporary Bulgaria, much of it by Bulgarian authors. Birkner remarked that "in Bulgaria, anthropological research has been conducted in an exemplary fashion and to an extent which has been hardly equalled, and never surpassed anywhere." ${ }^{14}$ Did anthropological research in Bulgaria really justify such an assessment? One thing can be said with certainty: German interest in the tradition of physical anthropology in Bulgaria had been rather slight up to then. It is therefore conspicuous that the increased attention came just as the new allies were compelled to close ranks. But to do justice to Bulgarian anthropology, we should not confine our attention to the well-meaning, but condescending, opinions of German contemporaries, but rather examine its origins and ideological ramifications. To do this, it would serve us well to compare them with parallel developments in Bulgaria's rival Serbia. ${ }^{15}$

There were abundant similarities between the two countries. The establishment of a national language as well as the collection of "folk poetry" and ethnographic objects and their ensuing canonization as "folk culture," played an important role in constructing national borders and a national "soul." Around the turn of the twentieth century, political geography, archaeology, prehistory, and physical anthropology joined philological and ethnographic endeavors. The national elites of Serbia and Bulgaria both felt that their countries, stuck in a post-Ottoman setting and bound by the regulations of the Congress of Berlin of 1878, were in a subaltern position vis-à-vis the European powers. Borders drawn in Berlin left nationalists grumbling. The two countries' national elites employed a variety of academic disciplines to legitimize their territorial aspirations-a process that eventually led to their becoming enemies in the Second Balkan War. This chapter will concentrate on the specific role physical anthropology played in that process.

13 Ibid., 22-23; Loritz, "Über die Herkunft des südbulgarischen Dolichocephalus," 25-26.

14 Birkner, "Die anthropologische Erforschung Bulgariens."

15 A short assessment of Greek anthropology until the end of the First World War can be found in Sevasti Trubeta, "Anthropological Discourse and Eugenics in Interwar Greece," in Blood and Homeland: Eugenics and Racial Nationalism in Central and Southeast Europe 1900-1940, eds. Marius Turda and Paul J. Weindling (Budapest: Central European University Press, 2007), 124-125. 


\section{“... Killing Something": The Hierarchical Setting of Anthropology in the Balkans}

Physical anthropology in the Balkans began with the reproduction and application of knowledge acquired by students in the German Reich and the Habsburg monarchy. The Balkan scholars' position was not an easy one: Their methods would be measured by the standards of contemporary European anthropology, and they had to decide whether they should also adopt its models or if they should develop their own models, which might push their research in new directions. In either case, their own nations were the focus of interest, generating parallel efforts to render the discipline relevant within the local academic communities and to demonstrate on the international level that their findings were more than just appendices to existing studies.

The pivotal question, however, was how to deal with the verdicts of western and central European predecessors. The anatomists Sámuel Henriket Scheiber (1834-1906) and Isydor Kopernicki (1825-1891) had been the first to examine the crania of several Bulgarians who had died in a hospital in Bucharest, ${ }^{16}$ but it was others, under the influence of the "Eastern Question" that had flared up again in 1875, who interpreted their results. Thus, the French armchair anthropologist Alexandre Abel Hovelacque (1843-1896) declared: “The Bulgarian appears to be a Tartar who has traded his own language for a Slavic one." ${ }^{17}$ Rudolf Virchow (1821-1902) was inclined to believe that Bulgarians were of Finnish or Turkish origin, agreeing with Hovelacque that, if they were Slavs, they were so by virtue of their language alone. ${ }^{18}$ He turned his attention to the Bulgarians in 1877, calling them "the tribe who, at the moment, is in the foreground of political interest and whom, we must say, the fight is about." 19 The earliest exhaustive anthropological examinations of the western South Slavs (Serbs, Croats, Bosnians, and Slovenes) were conducted by the Austrian anatomist Augustin

16 Sámuel Henriket Scheiber, "Tabelle mit den Maassen von 5 Bulgarenschädeln," Verhandlungen der Berliner Gesellschaft für Anthropologie, Ethnologie und Urgeschichte [Sitzung vom 10. Mai 1873] (1873): 94-97; Jsidore Kopernicki, "Sur la conformation des cranes bulgares," Revue d'Anthropologie 4 (1875): 68-96.

17 Alexandre Abel Hovelacque, "Sur deux crânes bulgares," Bulletins de la Société d'anthropologie, 2nd ser., 10 (1875): 429.

18 Rudolf Virchow, "Die nationale Stellung der Bulgaren," Verhandlungen der Berliner Gesellschaft für Anthropologie, Ethnologie und Urgeschichte [Sitzung vom 11. Februar 1877] (1877): 74-75; D. Kadanoff and St. Mutafov, "Rudolf Virchows Beobachtungen an Schädeln von Bulgaren im Lichte neuer anthropologischer Untersuchungen," Zeitschrift für die gesamte Hygiene und ihre Grenzgebiete 18, no. 6 (1972): 458-461.

19 Virchow, “Die nationale Stellung der Bulgaren," 70-71. 
Weisbach (1837-1914) from the late 1860s through the turn of the century. ${ }^{20}$ His interminable anthropometric tables do little to convey the glamor the Balkans possessed for Western amateurs in search of thrills and prestige. The British physician and ethnologist John Beddoe (1826-1911) promoted scientific pursuits in Ottoman Macedonia to the leisured classes:

Here are fine opportunities for any enterprising Englishmen with money and a taste for travel and adventure, and with sufficient brains to be able to pick up a language. But alas! Such men usually seem to care for nothing but 'killing something., ${ }^{21}$

When they published their findings, Western anthropologists only rarely provoked negative reactions from native intellectuals. One of the few criticisms on record comes from the Serbian ethnographer Tihomir R. Đorđević (18681944), angered by the Swiss anthropologist Eugène Pittard's (1867-1962) hasty assessment of the racial makeup of the Serbs. He complained about the arrogance of Western researchers whose statements were considered valid even when they had no foundation in reality. ${ }^{22}$

The earliest representatives of Bulgarian anthropology apparently took no offence at their country's subaltern position in European anthropology, nor to the fact that they were trained on colonial "material" before attending to their compatriots. The preeminent Bulgarian anthropologist, the physician Stefan Vatev (1866-1946), began his career as a student of Felix von Luschan (18541924). He helped the renowned anthropologist measure some one hundred Africans on display at the German Colonial Exhibition of 1896 in Berlin. ${ }^{23}$ The second most important Bulgarian anthropologist, Krum Drončilov (1889-

20 On Weisbach, see Brigitte Fuchs, "Rasse," "Volk," Geschlecht: Anthropologische Diskurse in Österreich 1850-1960 (Frankfurt a.M.: Campus, 2003), 139-145; idem, "'Kultur' und 'Hybridität': Diskurse über 'Rasse,' Sexualität und 'Mischung' in Österreich 1867 bis 1914." Austrian Studies in Social Anthropology 1 (2005), http://www.univie.ac.at/alumni.ethnologie/journal/ volltxt/Artikel\%201\%20_Fuchs.pdf; Christian Promitzer, "The Body of the Other: 'Racial Science' and Ethnic Minorities in the Balkans," Jahrbücher für Geschichte und Kultur Südosteuropas 5 (2003): 28-29.

21 John Beddoe, The Anthropological History of Europe: Being the Rhind Lectures for 1891, revised to date (Paisley, UK: Gardner, 1912), 86-87.

22 Tihomir R. Đorđević, "Contribution à l’étude anthropologique des Serbes du royaume de Serbie, par Eugène Pittard," (Revue de l’école d’anthropologie de Paris, septembre 1910, 307-311)," Srpski Književni Glasnik 25 (1910): 615-618.

23 Стефан Ватев [Stefan Vatev], Принос към антропологическо изучаване на Българите [Contribution to the anthropological study of the Bulgarians], n.p., n.d. [Sofia 1900] (= excerpt from the journal Български преглед [Bulgarian Survey] 6, no. 4 (1900): 1; on Luschan's role at the Colonial Exhibition, see Andrew Zimmerman, Anthropology and Antihumanism in Imperial Germany (Chicago, IL: University of Chicago Press, 2001), 30-35. 


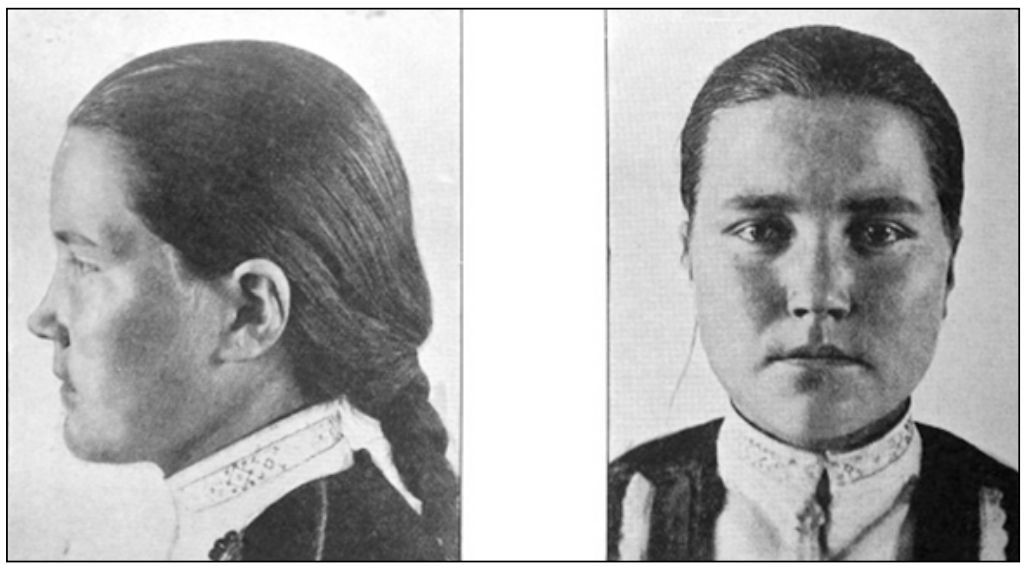

Figure 1. The original caption reads: "Bulgare. Race vistulienne ou Orientale Mélangée de Sang Turc." Source: J[oseph] Deniker, "Les Six Races Composant la Population Actuelle de l'Europe," The Journal of the Anthropological Institute of Great Britain and Ireland 34 (1904): plate xiii.

1925), was also a disciple of Luschan trained in Negeranthropologie, as he called it. Drončilov was entrusted with measuring the skulls of deceased railway construction workers in the German colony of Cameroon. ${ }^{24}$ In Bulgaria, the close relationship with German anthropology resulted in an uncritical attitude toward Western models generally. That tolerance is reflected in an affirmative review of foreign literature on the Bulgarians published by Vatev in $1910 .{ }^{25}$

Mentors, like the French anthropologist M. Joseph Deniker (1852-1918), allowed Stefan Vatev access to international anthropological journals-coups somewhat tarnished by Deniker's addition of condescending commentary. ${ }^{26}$ Vatev did, on one occasion, question Deniker's interpretation of a photograph of a Bulgarian woman he had sent him (Figure 1). In a widely noted lecture on the six races of contemporary Europe, Deniker had included the photograph as an example of the Eastern race mixed with Turkish blood. "We want to remark," Vatev wrote,

24 Krum Drontschilow, "Metrische Studien an 93 Schädeln aus Kamerun," Archiv für Anthropologie, n.s., 12 (1913): 161-183.

25 Стефан Ватев [Stefan Vatev], Чужда литература по антропологията на българите [Foreign literature on the anthropology of the Bulgarians] (Sofia: Държавна печатница [State Stationary Office], 1910).

26 S. Wateff, "Contribution a l'étude anthropologique des Bulgares," Bulletins et mémoires de la Société d'Anthropologie de Paris, 5th ser., 5 (1904): 437-458; M. Joseph Deniker, "Les Bulgares et les Macédoniens: Note complémentaire à la communication du Dr Wateff," Bulletins et mémoires de la Société d'Anthropologie de Paris, 5th ser., 5 (1904): 458-466. 
that Deniker wrongly considers this Bulgarian woman from a village near Sofia as being a mixture with Turkish blood. It is known that Turks never became Christians or Bulgarians - it was the other way around. In the region of Sofia, there were always only small numbers of Turks; and they lived solely in the towns; thus it is hard to accept that this type which is rather common in the region of Sofia contains an accidental mixture with Turkish blood. ${ }^{27}$

As Vatev's criticism was published only in Bulgarian, it had no international repercussions. The incident reveals the uncomfortable subaltern position of native scholars. They ran the risk of being reduced to humble collectors of anthropological material for Western colleagues, whose high-handed judgments on the makeup and origins of local populations upheld the image of the Balkans as heteronomous and impervious to outside influences. This attitude came to its full expression in the verdict pronounced by William Z. Ripley (1867-1941) in his book Races of Europe:

The Balkan Peninsula [...] has been unfortunate from the start. The reason is patent. It lies in its central or rather intermediate location. It is betwixt and between; neither one thing nor the other. Surely a part of Europe, its rivers all run to the east and south. "By physical relief it turns its back on Europe," continually inviting settlement from the direction of Asia. It is no anomaly that Asiatic religions, Asiatic institutions, and Asiatic races should have possessed and held it; nor that Europe, Christianity, and the Aryan-speaking races should have resisted this invasion of territory, which they regarded in a sense as their own. In this pull and haul between the social forces of the two continents we finally discover the dominant influence, perhaps, which throughout history has condemned this region to political disorder and ethnic heterogeneity. ${ }^{28}$

\section{In Search of the Nation: Bulgarian Anthropology up to the Balkan Wars}

Vatev's criticism of Deniker shows the power of interpretation in the field of physical anthropology. His rebuttal did not exhaust itself in a general complaint about casual assessments by Western researchers; it directly addressed a prejudice that merged Christian Bulgarians with Muslim Turks, a "contamination" already present in the "Tirk oder Griech" of the early eighteenth-cen-

27 Стефан Ватев [Stefan Vatev], "Les six races composant la population actuelle de l'Europe, par le Dr J. Deniker," Периодическо списание на Българското книжовно дружество в София [Periodical Journal of the Bulgarian Literary Society in Sofia] 18, nos. 7-8 (1907): 645.

28 William Z. Ripley, The Races of Europe: A Sociological Study (New York: Appleton, 1899), 402. 
tury Austrian Völkertafel. ${ }^{29}$ "Decontamination" for Vatev entailed distancing from the Ottoman legacy and the rejection of interbreeding with the Turks (while not excluding the possibility of racial mixtures with other populations). In Bulgarian nationalism, Turks and other Muslim minorities figured on the same subaltern level as the whole population of the Balkan Peninsula in the mind of Western anthropologists-a symbolic complex that Milica BakićHayden has called "nesting orientalisms." 30

How did such attitudes manifest themselves in Vatev's anthropological practice? In 1896, a committee for large-scale studies of the "Bulgarian Fatherland" was founded in Sofia. The committee planned a monograph on the anthropology and physiology of the Bulgarian population which would continue the examinations performed by the Lithuanian Ivan Juriev Basanovič (Jonas Yuro Bansaovichjus, 1851-1928) in northern Bulgaria in the 1880s. Basanovič had arrived as one of many foreign physicians helping to establish a public health system in the new state. During his time as district physician in the northwestern Bulgarian town and region of Lom, he had examined 185 women and nearly 2,500 men, coming to the conclusion that the Bulgarians were of Thracian origin. ${ }^{31}$

It would not be easy to surpass Basanovič's pioneering work. This could only be achieved by confronting the ultimate question, as Vatev explained:

The Bulgarians-history tells us - are a mixture of Slavs and Bulgarians of a Finnish tribe; Bulgaria, however, in the distant past was the road and guest house for many passing peoples. Out of the remnants of the former peoples who have moved and lived on our soil, out of the remnants of our forefathers and out of the study of the contemporary Bulgarian, the task of the anthropologist of the Bulgarian will be to determine by comparison which tribes they were, which tribe the Bulgarian one was, when and how it was mixed with the Slavic one, and whether the modern Bulgarian represents an independent Slavic type, a Bulgarian one, or a mixture of both of them, or of even more types. ${ }^{32}$

29 Zoran Konstantinović, "'Tirk oder Griech': Zur Kontamination ihrer Epitheta," in Europäischer Völkerspiegel: Imagologisch-ethnographische Studien zu den Völkertafeln des frühen 18. Jahrhunderts, ed. Franz K. Stanzel (Heidelberg: Winter, 1999), 299-314.

30 Milica Bakić-Hayden, "Nesting Orientalisms: The Case of Former Yugoslavia," Slavic Review 54, no. 4 (1995): 917-931.

31 Иван Бассанович [Ivan Basanovič], "Материали за санитарната етнография на България І. Ломският окръг (1880-1889)" [Materials for the sanitary ethnography of Bulgaria I. district of Lom (1880-1889)], Сборник за народни умотворения, наука и книжниа [Almanac of Folklore, Science, and Literature] 5 (1891): 26-32, 38-40; see Y[ordan]. A. Yordanov, "One Hundred Years of Anthropological Studies in Bulgaria," Annals of Anatomy 175 (1993): 385-387.

32 Стефан Ватев [Stefan Vatev], "Антропологическо изследване на България” [Anthropological research in Bulgaria], Български преглед [Bulgarian Survey] 5, no. 1 (1898): 148. 
With the cooperation of the War Ministry, Vatev supervised military physicians who took anthropological measurements of about six thousand soldiers stationed throughout the country. He informed Ranke in Munich of his preliminary results, and Ranke convinced him to expand the investigation to schoolchildren, following the example of Virchow and the German Society for Anthropology, Ethnology, and Prehistory. The Bulgarian Ministry of Education supported the plan, ordering Bulgarian teachers to follow Vatev's instructions, ${ }^{33}$ and, by 1901, Vatev had at his disposal the eye, hair, and skin color of 236,884 schoolchildren along with 31,469 soldiers. With the support of the Exarchate of the Bulgarian Orthodox Church, he also managed to acquire the data of almost thirty thousand pupils attending the schools run by the Exarchate in the Ottoman provinces of Thrace and Macedonia. ${ }^{34}$

Ranke had suggested retaining the hierarchy of Virchow's school statistics, and Vatev followed his advice. Virchow had differentiated between a favorable blond type, a less desirable brunette type, and a mixed type. Vatev kept the German hierarchy, even though the dark and mixed types (at 47 and 44 percent, respectively) were more common among the Bulgarian population than the blonds with only 9 percent. Fair-skinned subjects were more common in western Bulgaria than in the east. According to Vatev's figures, the distribution of the blond, dark, and mixed types among the Bulgarian population of Macedonia and Thrace was almost the same as among that of Bulgaria proper $^{35}$ - a result of potential utility for national policy. Vatev's results echoed those of Vasil Kănčov (1862-1902), who had presented ethnographic statistics on the population of Macedonia to show that Bulgarians were a single entity, whether inside or outside the principality. ${ }^{36}$ However, Vatev's anthropological findings did not gain similar popularity in Bulgaria.

33 Vatev, "Contribution to the Anthropological Study of the Bulgarians," 2-4; on the German school statistics, see Zimmerman, Anthropology and Antihumanism, 135-146.

34 Stefan Wateff, "Anthropologische Beobachtungen an den Schülern und Soldaten in Bulgarien," Correspondenz-Blatt der deutschen Gesellschaft für Anthropologie, Ethnologie und Urgeschichte 32, no. 4 (1901): 29-30; idem, "Anthropologische Beobachtungen der Farbe der Augen, der Haare und der Haut bei den bulgarischen Schulkindern in der europäischen Türkei," Correspondenz-Blatt der deutschen Gesellschaft für Anthropologie, Ethnologie und Urgeschichte 33, no. 3 (1902): 23-24.

Idem, "Anthropologische Beobachtungen an den Schülern und Soldaten"; idem, "Anthropologische Beobachtungen der Farbe der Augen." [Macedonia: Ethnography and statistics] (Sofia: Държавна печатница [State Stationary Office], 1900). 
Like Virchow, whose school study had tried to answer the question of whether there were differences between German and Jewish children, Vatev directed his attention to differences between Bulgarians and ethnic minorities, including Turks, Pomaks (Slavic-speaking Muslims), Armenians, Gagauz (Orthodox Christian Turks), and Jews. He gathered data on 54,734 pupils from ethnic minorities. To his embarrassment, the blond type, at 13 percent, was better represented among the Turks and the Pomaks than among the ethnic Bulgarians. Vatev published these unwelcome findings only in German, avoiding a direct comparison between ethnic Bulgarians and Muslim minorities. ${ }^{37}$ In any case, he evaded a final assessment of the racial origins of the Bulgarians, which had been the original motive for the tremendous administrative effort required to measure a quarter of a million people. Vatev published the results in Bulgarian only in 1939, when they were already outdated and marginalized by more recent research. ${ }^{38}$

\section{A Slovene in Serbia: Serbian Anthropology up to the Balkan Wars}

The basis for the establishment of physical anthropology in Serbia was different. The leading figure in the natural sciences was the geographer Jovan Cvijić (1865-1927). Anthropological measurements played a limited role; the group of young Serbian scholars who gathered around him were more interested in linking geography with ethnography, describing the somatic traits of

37 Stefan Wateff, "Anthropologische Beobachtungen der Farbe der Augen, der Haare und der Haut bei den bulgarischen Schulkindern von den Türken, Pomaken, Tataren, Armenier, Griechen und Juden in Bulgarien," Correspondenz-Blatt der deutschen Gesellschaft für Anthropologie, Ethnologie und Urgeschichte 34, nos. 7-8 (1903): 58-60.

38 Стефан Ватев [Stefan Vatev], Антропология на Българите [Anthropology of the Bulgarians] (Sofia: Книпеграф [Knipegraf], 1939). Apart from Vatev, the statistician Jakim Pomadov evaluated the body size of about one hundred thousand Bulgarian military recruits from 1897 until 1900 in order to assess the racial composition of the Bulgarian population, whereby he differed between a larger "Slavic" and a smaller "Thracian" type-see Помадов Яким [Pomadov Jakim], "Военна антропометрия: Резултати от измеранията височината и гърдите на младежите в България през 1897-1900" [Military anthropometrics: Results of the measurements of the body height and the chests of adolescents in Bulgaria in the years of 1897-1900], Трудове на българското природоизпитателно дружество [Papers of the Bulgarian Society of Natural History] 2 (1904): 173-199. 
local populations they studied only in vague terms. ${ }^{39}$ Although Cvijić was not persuaded of the potential of physical anthropology $y^{40}$, he was impressed by Deniker's concept of the Adriatic or Dinaric Race. Its members were tall, with round skulls, dark hair and eyes, and brownish skin. To these somatic traits, Cvijić attached psychological traits associated with mountain men: masculinity, honor, chivalry, and heroism. The highlanders' realm was the "patriarchal regime" of the Balkan Peninsula. ${ }^{41}$

Cvijić was at least partly responsible for the arrival of the Slovene Niko Županić (also written Zupanič or Županič) (1876-1961) in Serbia in 1907. Županić became Serbia’s first scholar of physical anthropology. He had studied history in Vienna, but had also pursued a specialization in anthropology in Ranke's department in Munich, and was a member of the Viennese Anthropological Society. As a staunch adherent of Yugoslavism, he had little chance of an academic career in Austria-Hungary, but in Serbia he became curator of the Belgrade History and Arts Museum. ${ }^{42}$

39 See the anthropological observations in Rista T. Nikolić, "Poljanica i Klisura: Antropogeografski proučavanja" [Poljanica and Klisura: Anthropogeographical studies], in Naselja srpskih zemalja [Settlements of the Serbian lands], ed. Jovan Cvijić, vol. 3 (Belgrade: Državna Štamparija [State Stationary Office], 1905), 124-131; Jovan Erdeljanović, "Kuči: Pleme u Crnoj Gori" [Kuči: A tribe in Montenegro], in Naselja srpskih zemalja [Settlements of the Serbian lands], ed. Jovan Cvijić, vol. 4 (Belgrade: Državna Štamparija [State Stationary Office], 1907), 172-190, 344-345; on the school of Cvijić, see Conrad Clewing and Edvin Pezo, "Jovan Cvijić als Historiker und Nationsbildner: Zu Ertrag und Grenzen seines anthropogeographischen Ansatzes zur Migrationsgeschichte," in Beruf und Berufung: Geschichtswissenschaft und Nationsbildung in Ostmittel- und Südosteuropa im 19. und 20. Jahrhundert, eds. Markus Krzoska and Hans-Christian Maner (Münster: LIT, 2005), 265-297.

40 Jovan Cvijić, Balkansko poluostrvo [The Balkan Peninsula] (Belgrade: Srpska akademija nauka i umetnosti [Serbian Academy of Sciences and Arts], 1987), 328-329 (first published in French in 1918).

41 Idem, "Kulturni pojasi Balkanskoga Poluostrva" [Cultural circles of the Balkan Peninsula], Srpski književni glasnik [Serbian Literary Review] 6 (1902): 914-916; idem, The Balkan Peninsula, 361-375; Karl Kaser, "Peoples of the Mountains, Peoples of the Plains: Space and Ethnographic Representation," in Creating the Other: Ethnic Conflict and Nationalism in Habsburg Central Europe, ed. Nancy M. Wingfield (New York: Berghahn Books, 2003), 219-224; Christian Töchterle, "Wir und die Dinarier: Der europäische Südosten in den rassentheoretischen Abhandlungen vor und im Dritten Reich," in Südostforschung im Schatten des Dritten Reiches: Institutionen —Inhalte_Personen, eds. Mathias Beer and Gerhard Seewann (Munich: Oldenbourg, 2004), 167-170.

42 Christian Promitzer, "Niko Županič in vprašanje jugoslovanstva: Med politiko in antropologijo (1901-1941)" [Niko Županič and the issue of Yugoslavism: Between politics and anthropology (1901-1941)], Prispevki za novejšo zgodovino 
In Bulgaria, the political uses of large anthropometric studies were limited, partly because the results were not in line with expectations. But it is also safe to say that immediate political application was not the chief aim of the inductive, liberal brand of German anthropology $y^{43}$ in which Vatev had been trained. Županić, on the other hand, had already joined German anthropology's turn toward "Nordic anthroposociological ideas." ${ }^{34} \mathrm{He}$ gave his work explicit ideological overtones from the beginning. Before commencing fieldwork, he analyzed descriptions of peoples in ancient and Byzantine texts to help preformulate a "racial history" of the Balkans.

The essence of Županić's thought is contained in a long article on the "System of the Historical Anthropology of the Balkan Peoples," published in the Serbian language as well as in a shorter article in German on the Illyrians. Županić believed he could justify the round heads and dark skin of the South Slavs by assuming the existence of a primordial population of brachycephalic brunettes. This population had mixed with xanthodolichocephalic (i.e., light-skinned, blond-haired, blue-eyed dolichocephalic) Aryan newcomers, Indo-Europeans who reached the Balkans in waves beginning in the second millennium B.C.E. They mixed repeatedly with the local population, but the domestic brachycephalic elements predominated over the more recent dolichocephalic one. Influenced by the rediscovery of Mendelian genetics, his hypothesis explained the gradual brachycephalization of newcomers to the Balkan Peninsula: Round heads were a dominant trait. Brachycephalization had progressed to the furthest extent among the Albanians, whose Illyrian ancestors had been the first Indo-European group to settle on the peninsula. The next group to fall victim to the process was the Greeks, who had migrated to the Balkans in the second millennium B.C.E.; after two thousand years of constant mixing, modern Greeks bore almost no resemblance to their ancient progenitors. The South Slavs, arriving in the sixth century, were only the most recent to undergo brachycephalization. ${ }^{45}$

[Contributions to Contemporary History] 41, no. 1 (2001): 14; “Vorstand und Mitglieder der Anthropologischen Gesellschaft in Wien nach dem Stande vom 20. März 1907," Mitteilungen der Anthropologischen Gesellschaft in Wien (MAGW) 37 (1907), Sitzungsberichte 1906-1907: 11.

43 Benoit Massin, "From Virchow to Fischer: Physical Anthropology and 'Modern Race Theories' in Wilhelmine Germany," in Volksgeist as Method and Ethic: Essays on Boasian Ethnography and the German Anthropological Tradition, ed. George W. Stocking (Madison, WI: University of Wisconsin Press, 1996), 79154.

44 Idem, "From Virchow to Fischer," 134.

45 Niko Županić, "Sistem istorijske antropologije balkanskih naroda" [System of the historical anthropology of the Balkan peoples], Starinar. Organ Srpskog arheološkog društva [Antiquary. Organ of the Serbian Archaeological 
Županić's narrative is an inventive extension of typical racial hierarchies to the Balkans and, at the same time, a defence of the racial superiority of the originally Nordic South Slavs. This becomes explicit when Županić references the historian Jakob Philipp Fallmerayer (1790-1861), who had become famous for his statement that "auch nicht ein Tropfen echten und ungemischten Hellenenblutes fließt in den Adern der christlichen Bevölkerung des heutigen Griechenland" [not one drop of genuine and unadulterated Hellenic blood flows in the veins of the Christian population of modern Greece]. Županić declares:

Fallmerayer is wrong when he thinks that the Slavs have contaminated the Greeks; the development goes the other way around. If xanthodolichocephaly is something noble, as many French and German anthropologists and historians argue ([Arthur de] Gobineau, [Georges] Vacher de Lapouge, L[udwig] Woltmann, H[ouston] S[tewart] Chamberlain, L[udwig] Wilser, K[arl] Penka, L[udwig] Reinhardt), then the Slavs could only invigorate, uplift and ennoble the Greeks and bring them closer to their ancient, fair-haired ancestors. ${ }^{46}$

By quoting such sources, Županić took sides with the most notorious racial theories and the German and French anthropologists who were their staunchest advocates. He did not question the right of the Nordic/Aryan (he used both terms) master race to the top position. He absolved the South Slavs of responsibility for the dominance of brachycephales on the Balkan Peninsula; their appearance had originally been Nordic, like that of the ancient Greeks. It was to their credit that they had arrived to delay the brachycephalization of the entire peninsula. However, in the long run, because of their noble sacrifice, the South Slavs had to bear the consequences: They became Dinaric.

With regard to the Serbs' immediate neighbors, Županić appeared to echo Serbian pretensions to Albanian-settled territories in western Macedonia and Bulgaria. He expressed doubt that the Albanians could be called a "nation"; they were few in number, lacked a common folk tradition, culture or literary language, and were divided among three confessions. ${ }^{47}$ Reinterpreting data gathered by Vatev, Županić concluded that the skull shapes and complexions of the population of western Bulgaria and western Macedonia resembled that of the Serbs of Bosnia and Herzegovina. ${ }^{48}$

Society], n.s., no. 2 (1907): 167-189; idem, "Sistem istorijske antropologije balkanskih naroda" [System of the historical anthropology of the Balkan peoples], Starinar. Organ Srpskog arheološkog društva [Antiquary. Organ of the Serbian Archaeological Society], n.s., no. 3 (1908): 1-70; Niko Županić, "Die Illyrier (Ein Profil aus der historischen Physioanthropologie der Balkanhalbinsel)," MAGW 37 (1907), Sitzungsberichte 1906-1907: 21-24.

47 Ibid., 2.

48 Ibid., 60-61. 
Interestingly, despite his Yugolavism, Županić rejected the idea of a SerboCroatian Volk, which was vehemently discussed at the time. Županić considered Serbs and Croats, language notwithstanding, to be two ethnic groups, like the Franconians and Bavarians who nonetheless belonged to a larger German nation. ${ }^{49}$ His conclusion may have something to do with his Slovene origins and the ongoing debate among Serbian intellectuals on whether Slovenes could be included in the Yugoslav program. By denying an anthropological commonality to Serbs and Croats, Županić was presumably led by a tacit wish to position the Slovenes, whose language was not as closely related to Serbian or Croatian, on the same level as Serbs and Croats. Together, they would form the larger nation of the Yugoslavs.

With his theses, Županić made a name for himself as an anthropologist in both Serbia and Slovenia. Shortly thereafter, he conducted his first anthropological examinations of three hundred inhabitants of Serbian villages on the border between Croatia and Carniola, which is a part of modern Slovenia. The study, published in 1912, ${ }^{50}$ was "the first anthropological work in Serbian science to rest on precise measurements," as the geographer Jevto Dedijer (18801918) stressed in a review. ${ }^{51}$

\section{POWs and Recruits: Bulgarian and Serbian Anthropology in the Balkan Wars}

Wartime provides unusual opportunities for anthropologists to make examinations of material living and dead, as the history of the anthropological sciences indicates. Wartime rallies large numbers of young men in the most enjoyable time of their lives and from different countries and regions, allowing easy comparison of physical traits. Anthropologists are spared the travails of long expeditions as well as the tempers and superstitions of peasants. ${ }^{52}$

49 Ibid., 51.

50 Idem, Žumberčani i Marindolci: Prilog antropologiji i etnografiji Srba u Kranjskoj [The people of Žumberak and Marindol: Contribution to the anthropology and ethnography of the Serbs in Carniola] (Belgrade: Državna štamparija [State Stationary Office], 1912); see Christian Promitzer, "'Gute Serben': Ethnologen und Politiker über die Identität der Serben in der Bela krajina," in Umstrittene Identitäten: Ethnizität und Nationalität in Südosteuropa, ed. Ulf Brunnbauer (Frankfurt a. M.: Lang, 2002), 173-199.

51 Jefto Dedijer, "D-r. Niko Županić, Žumberčani i Marindolci," Letopis Matice Srpske [Annual of Matica Srpska] 87, no. 286 (1912): 85.

52 Niko Županić, "Pontijski Bugari: Prilog fizičkoj antropologiji Balkanskog istoka" [The Pontic Bulgarians: Contribution to the physical anthropology of the Balkan island], Prosvetni glasnik: Službeni list Ministarstva prosvete i crkvenih 
These words were not written in World War I; they come from a 1913 article by Županić, who may have been the first European anthropologist to undertake systematic examination of prisoners-of-war (POWs). The first in Serbian custody were Ottomans captured during the First Balkan War. Županić was particularly interested in Turkish POWs from Anatolia: "The anthropologist is offered an exceptional possibility to study this tribe, who through five centuries has ruled the Balkan Peninsula, delaying the cultural and political development of the Serbs and Bulgarians and imposing Islam and Eastern ways of life." ${ }^{33}$

For the first six months of 1913, Županić was in Vienna under orders of the Serbian government to drum up support for Serbian aims. By the time he returned to Belgrade in early June, most of the Turkish POWs had been sent home. Only two or three hundred were still being held in the fortress in Belgrade, awaiting orders for repatriation. They were already free in legal terms and stood under the protection of the German embassy. Since the fortress also served as a quarantine for Serbian soldiers affected by epidemics-mainly cholera-Županić was advised to abandon his plans, but the commander of the fortress eventually allowed him access. ${ }^{54}$ He selected a Pomak, a Slavicspeaking Muslim, from the POWs and used him as an interpreter to ask the other prisoners about their age and birthplace ${ }^{55}$ before acquiring data including height, skull length, width and circumference, assorted distances, various facial indices, and skin, beard, hair, and eye color.

After an initial group had been examined, the rest refused their cooperation. ${ }^{56}$ Županić rose to the challenge:

But what cannot be reached by good words can be reached with force. I ordered the garrison [of the fortress], mainly peasants with sheepskin caps on their heads, long bayonets on their rifles, and otherwise dressed in peasant clothes, to take up

poslova [Educational Review: Official Paper of the Ministry of Education and Religious Affairs] 34, no. 7 (1913): 967.

53 Idem, "K antropologiji osmanskih Turaka angorskog i konijskog vilajeta" [On the anthropology of Ottoman Turks from the Vilayets of Angora and Konya], Etnolog: Glasnik kr. Etnografskega muzeja v Ljubljani [Ethnologist: Review of the Royal Ethnographic Museum in Ljubljana] 1 (1926-1927): 87.

54 Ibid., 87-88.

55 In a more sophisticated form, the same procedure was applied in the Austrian mass examinations of POWs during the First World War. See Margit Berner, "Forschungs-Material Kriegsgefangene: Die Massenuntersuchungen der Wiener Anthropologen an gefangenen Soldaten 1915-1918," in Vorreiter der Vernichtung? Eugenik, Rassenhygiene und Euthanasie in der österreichischen Diskussion vor 1938, eds. Heinz Eberhard Gabriel and Wolfgang Neugebauer (Vienna: Böhlau, 2005), 174.

56 Županić, "On the Anthropology of Ottoman Turks," 88. 


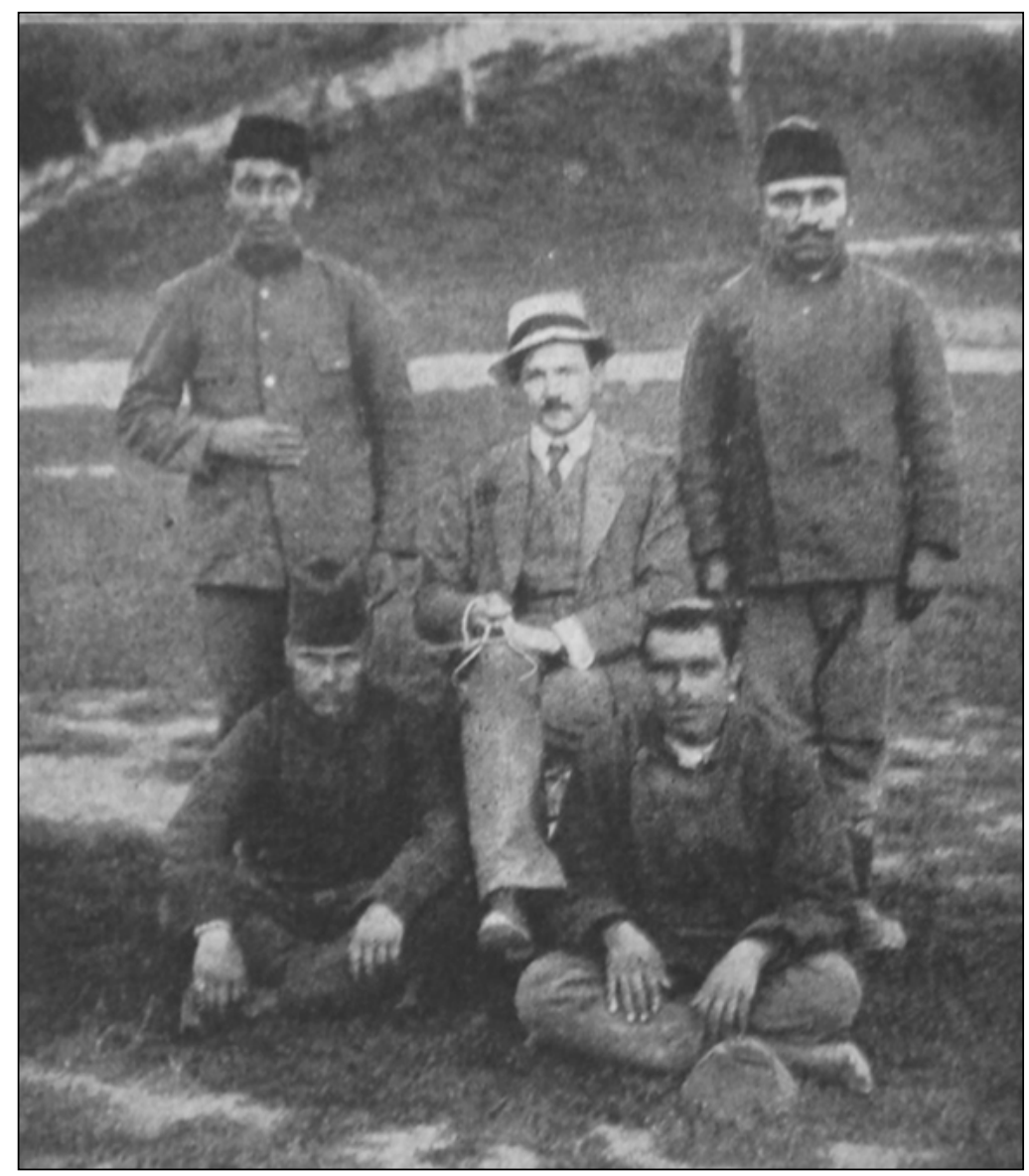

Figure 2. Niko Županić with a caliper surrounded by his Turkish interpreters and informants at the Fortress of Belgrade (1913). Source: Niko Županić, "Visina uzrasta Turaka Osmanlija," Vjesnik Etnografskog Muzeja u Zagrebu 2 (1936): 3-10, image from p. 5.

position in formation. And with some of them I went to the room of the Turks, and threatened that everybody who resisted examination would be shot. I gave them ten minutes to think about it, and went back to my office. And after some time, the translator appeared with five Turks who displayed compliance. For fear that the German embassy could at any time recall the Turkish POWs, I quickly examined 155 Turks, 24 from Europe and 131 from Asia Minor. ${ }^{57}$

The asymmetrical distribution of power between the anthropologist and his subjects is all too clear in the prisoners' humiliation. Županić's photographs

57 Ibid. 
(Figure 2) clearly visualize "the power of the scientist over the subject"58 and were harbingers of the photographs that German and Austrian anthropologists would take in the course of mass examinations of POWs two years later in the Great War. Županićs findings were not particularly noteworthy; he concluded that the Ottoman Turks were a subset of the central Asian Turks, though the epicanthal fold was less common among them, the reason being that the Ottoman Turks had assimilated the ancient ethnic substrate of Asia Minor. ${ }^{59}$ Županić went on to state that Ottoman Turks had no racial link to the Muslim South Slavs of Bosnia and Herzegovina, who, like other South Slavs, were taller than Turks. ${ }^{60}$ Cleansing the Bosnian Muslims of affinity to the Turks was in line with the Yugoslav program, which welcomed South Slavs from the western Balkans regardless of religious belief.

In an ironic twist, only a few years later, the Austrian anthropologist Josef Weninger (1886-1959) would examine Serbian POWs, find them to resemble Turks, and declare them Asians. The Ottoman Empire was allied with AustriaHungary at the time, but Turks were still regarded as "the quintessential racial and cultural 'other' in the history of the Austrian Empire."61

The Second Balkan War in the summer of 1913 offered Županić a renewed opportunity to measure POWs, in this case 179 Bulgarians from eastern districts of Bulgaria near the Black Sea. The examinations took place in the same Belgrade fortress, but under more congenial circumstances than with the Turkish POWs, perhaps because Bulgarians were viewed as closely related to Serbs. Although adversaries with respect to the Macedonian question, they had suffered similar fates under the "Ottoman yoke." Županić was supported in his work by two Bulgarian university students who were likewise POWs. ${ }^{62}$ His findings confirmed his a priori opinion, formulated in his "system," that the population of northeastern Bulgaria was shorter in height than other Bulgarians. He suggested that their small size might be a result of immigration

58 Andrew D. Evans, "Capturing Race: Anthropology and Photography in German and Austrian Prisoner-of-War Camps during World War I," in Colonialist Photography: Imagining Race and Place, eds. Eleanor M. Hight and Gary D. Sampson (London: Routledge, 2002), 236.

59 Županić, "On the Anthropology of Ottoman Turks," 128-129.

60 Idem, "Visina uzrasta Turaka Osmanlija" [The body size of the Ottoman Turks], Vjesnik Etnografskog muzeja u Zagrebu [Bulletin of the Ethnographic Museum in Zagreb] 2, nos. 3-4 (1936): 9.

61 Andrew D. Evans, "Anthropology at War: Racial Studies of POWs during World War I," in Worldly Provincialism: German Anthropology in the Age of Empire, eds. H. Glenn Penny and Matti Bunzl (Ann Arbor, MI: University of Michigan Press, 2003), 225.

62 Županić, "The Pontic Bulgarians," 967-969. 
by "Mongolian" elements from southern Russian and central Asia during the Middle Ages. ${ }^{63}$

Županić published the results of his Bulgarian POW study in late 1913 in the journal of the Serbian Ministry of Education. ${ }^{64}$ Due to its largely descriptive character and the distraction posed by the Great War, the article had no major impact in Serbia or on other anthropological studies of POWs elsewhere. The same was true of his examinations of Turkish POWs. Županić was supposed to give a paper, Zur physischen Anthropologie der Osmanischen Türken [On the Physical Anthropology of the Ottoman Turks] at the 45th General Meeting of the German Anthropological Society in August 1914, but the war intervened. ${ }^{65}$ Only after the war did the results of his examinations find an outlet, as two articles published in Serbian. ${ }^{66}$

Bulgarian anthropologists undertook no anthropological examinations of POWs. Vatev had withdrawn from extended fieldwork. In the autumn of 1912, shortly before the mobilization of recruits for the First Balkan War, the young Drončilov measured about 450 soldiers and policemen on leave in southwestern Bulgaria. When the war began, he was himself drafted, but with the help of military authorities succeeded in measuring 90 soldiers from the southern Bulgarian region of Plovdiv. The results of his examinations formed the backbone of his doctoral dissertation titled Contributions to the Anthropology of the Bulgarians, written under the supervision of Luschan and defended in 1914 in Berlin. Compared to the large-scale examinations of Stefan Vatev and Jakim Pomadov, the number of persons he screened was relatively small, but where Vatev and Pomadov had been assisted by draft boards and military physicians, Drončilov had to conduct all the measurements himself. Drončilov made measurements of various body parts, which he presented in his appendix for each individual in scrupulous detail. ${ }^{67}$

Unlike those of Županić in Serbia, Drončilov's conclusions were rather minimalistic, in line with the cautious assessments that had characterized the work of Vatev. Drončilov was notable in ranking scientific rigor above national interests. He agreed with Županić that the brachycephalic type was more common in west-

63 Ibid., 970.

64 Ibid.

65 Louis J. Pirc, "Iz življenja Dr. Nike Zupaniča” [From the life of Dr. Niko Zupanič], in Niko Zupanič, Slovenija vstani! Ameriškim Slovencem: Govor ki ga je imel pred Slovenci v Clevelandu 28. aprila 1916 [Slovenia, stand up! To the American Slovenes. Speech he gave before the Slovenes of Cleveland on 28 April 1916], (Cleveland, $\mathrm{OH}$ : Tiskarna "Clevelandske Amerike" [Printing House of the "Cleveland American"], 1916), xxviii.

66 Županić, "On the Anthropology of Ottoman Turks"; idem, "The Body Size of the Ottoman Turks."

67 Krum Drontschilow, Beiträge zur Anthropologie der Bulgaren (Braunschweig: Vieweg, 1914). 
ern Bulgaria, and that it displayed similarities with the Herzegovinian or Dinaric type ${ }^{68}$ With respect to the origin of the Bulgarians, he remarked laconically that "among the contemporary Bulgarians, apart from the Slavic one, there is also a quantitative significant representation of the Finnish element." ${ }^{69}$ His summary, however, was merely a modest reaffirmation of Vatev's claims of 1898.

\section{The Great War}

Given the research opportunities apparently provided by the Balkan Wars, it is surprising that anthropology in the Balkans was largely inactive during World War I.

In the case of Serbia, one explanation might be that, shortly after the Austro-Hungarian declaration of war, Belgrade was put under continuous heavy shelling. The king and the government as well as the intellectual elite, were evacuated to the city of Niš-among them Županić, who had recently become custodian of the anthropological section of the Serbian Ethnographic Museum. In early 1915, the Serbian government assigned Županić the task of advocating Yugoslav unification among the Entente. Consequently, he became a member of the Yugoslav Committee, a pressure group of South-Slavic émigrés from the Habsburg monarchy that commuted between London and Paris, lobbying for the creation of a Yugoslav state. ${ }^{70}$

The Bulgarian occupation of eastern and southern Serbia, parts of Kosovo, and what is now the Republic of Macedonia could have offered enviable opportunities to conduct anthropological examinations in situ. But without Vatev, neither the government nor the army developed an interest in supporting major anthropological studies as had been the case at the turn of the century. Drončilov, who served in the Bulgarian army, had to wait until early 1918 to obtain a permit from the First Bulgarian Army staff to conduct anthropological examinations in western Macedonia and Bulgarian-occupied Kosovo. With the support of local commanders, he measured around five hundred Slavic Macedonians and one hundred Albanians. ${ }^{71}$ Drončilov's research paralleled that of the Austrian

68 Ibid., 30-31.

69 Ibid., 32.

70 Ljubinka Trgovčević, Naučnici Srbije i stvaranje Jugoslavije 1914-1920 [The scientists of Serbia and the creation of Yugoslavia 1914-1920] (Belgrade: Narodna knjiga-Srpska književna zadruga [National Book-Serbian Book Cooperation], 1986), 26-27, 29-32, 93, 104, 108-110, 124, 157-158, 187-191, 272, 275, 278; Promitzer, "Niko Županič and the Issue of Yugoslavism," 15-18.

71 Крум Дрончилов [Krum Drončilov], "Материали за антропологията на българите. І. Македонските българи" [Materials for the anthropology of the Bulgarians: I. The Macedonian Bulgarians], Годишник на Софийският 


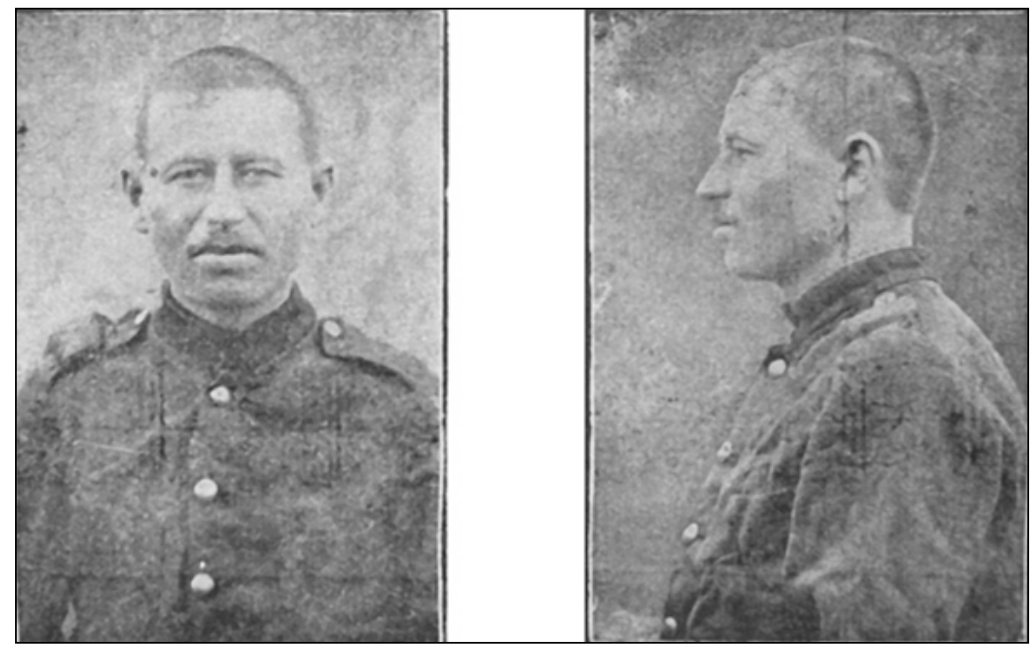

Figure 3. Albanian from the village Palčište/Pallçishti near Tetovo/Tetova in Macedonia. Source: Крум Дрончилов [Krum Drončilov], "Принос към антропологията на албанците" [Contribution to the anthropology of the Albanians], Списание на БАН [Journal of the Bulgarian Academy of Sciences] 21, клон-природо-математичен [Branch of Natural Science and Mathematics] 10 (1921): 111-134, section of photographs at the end of the article.

scholars Arthur Haberlandt (1889-1964) and Viktor Lebzelter (1889-1936), who, during the same period, examined over one hundred Albanians from the Austro-Hungarian occupation zones in Albania and Kosovo. ${ }^{72}$ But Drončilov failed to publish his results until the early 1920s, when their political uses had been mooted; both Macedonia and Kosovo were beyond postwar Bulgaria's reach. He no longer disavowed an alignment with long-term Bulgarian national policy, though making only sparing use of comments that could be construed as political. But his differing treatment of Slavic Macedonians and Albanians clearly expressed his bias. While conceding that there was no homogeneous anthropological type among the Slavic Macedonians, he did not question their

университет. І.Историко-филологически факултет [Yearbook of the University of Sofia. I. Faculty of History and Philology] 17 (1920-1921): 133-197; Idem, "Принос към антропологията на албанците" [Contribution to the anthropology of the Albanians], Списание на БАН [Journal of the Bulgarian Academy of Sciences] 21, клон природо-математичен [Branch of Natural Science and Mathematics] 10 (1921): 111-134.

72 Arthur Haberlandt and Viktor Lebzelter, "Zur physischen Anthropologie der Albanesen," Archiv für Anthropologie 17 (1919): 123-154. 
national affiliation as Bulgarians. ${ }^{73}$ With the Albanians, on the other hand, his way of proceeding recalls Županić:

The presented traits of the physical makeup of the Albanian population show in consequence that this population represents a colourful mixture of somatic elements. But it is still too early to answer the questions of how, when, and where these heterogeneous somatic elements gathered under a common culture, a common language, and a common ethnicity. ${ }^{74}$

Unlike the Macedonian Slavs, who were supposed to form part of the Bulgarian nation, the Albanians figured as an alien ethnic group, even when fighting in Bulgarian uniform, as the accompanying photographs show (Figure 3).

\section{Postwar Destinies}

In early 1919, Županić became a member of the "historical-ethnographic section," an advisory body to the official delegation of the recently founded Kingdom of Serbs, Croats, and Slovenes to the peace negotiations in Paris. Apart from coauthoring memoirs that supported Yugoslav territorial claims, ${ }^{75}$ he continued to utilize his racial theory for propaganda purposes.

In an article on "The First Inhabitants of the Yugoslav Lands," written in July 1918 and published in the first 1919 issue of the Revue Anthropologique, Županić reiterated his account of the Balkans as the "placenta" of brachycephalic populations. ${ }^{76}$ According to Županić, prehistoric "Mongolian" invaders brought brachycephaly to the Balkans, forever changing the long-headed, blond, blue-eyed South Slavs. ${ }^{77}$ In the American Journal for Physical Anthropology, the article was reviewed as a "useful anthropological sketch of the early inhabitants of the South-Slavic countries," but criticized for its "fanciful etymologies in trying to establish the Mongolian origin of the modern brachycephalic people."78

The article attacked "the gospel of pure Aryan origin" that Županić saw as dominating German science, ${ }^{79}$ but it was not a dismissal of Aryanism. While peace negotiations were still underway, Županić published Ave Illyria, a col-

73 Drončilov, "Materials for the Anthropology of the Bulgarians," 137, 166.

74 Idem, "Contribution to the Anthropology of the Albanians," 127.

75 Promitzer, "Niko Županič and the Issue of Yugoslavism," 18-19.

76 Niko Županić, Les premiers habitants des pays Yougoslaves: Ethnologie paléolithique et néolithique de I'Illyricum (Paris: Libraire Félix Alcan, 1919), 21.

77 Ibid., 21, 30.

78 Truman Michelson, "Les premiers habitants des pays Yougoslaves, by Županič," American Journal of Physical Anthropology 2 (1919): 343.

79 Županić, Les premiers habitants des pays Yougoslaves, 18-19. 
lection of essays in French financed by the government in Belgrade. One essay, "The Yugoslav Race and Blood," provided a racial explanation of South-Slavic unity, positing racial kinship between the South Slavs and the Albanians ${ }^{80}$ (to claim Albanian lands) and the South Slavs and the population of Veneto ${ }^{81}$ (to repudiate Italian claims to the eastern coast of the Adriatic). It included Županićs version of Aryan theory:

Although the Yugoslavs possess lots of Asian blood (melanobrachycephaly) and a little Hamitic blood (melanodolichocephaly), they are somatically and physically more Aryan than, for example, the Greeks, the Italians, the Spaniards, the southern French, the southern Germans, or the Rumanians. ${ }^{82}$

Consequently, the Yugoslavs were destined to play a major role in history.

Thus the South Slavs hope that, having poured out their blood in this war, they will continue the task for which they are chosen and prepared: regeneration in the east and the introduction of new elements into European civilisation. ${ }^{83}$

\section{Conclusion}

In both Serbia and Bulgaria, anthropology developed under German influence. In both countries, representatives of the discipline constituted a mere handful of researchers, and, for the most part, they conducted anthropology as a sideline heavily affected by their countries' subaltern positions in both the international arena and the academic world.

German anthropologists with direct influence in Bulgaria included Luschan at the University of Berlin and the Munich anthropologists Ranke and Birkner. Ranke also trained the Slovene racist Županić, Serbia's only committed anthropologist. Although he studied in Vienna, Županić showed scant influence of Austro-Hungarian anthropology, putting empirical data from Austro-Hungarian studies of Balkan populations (such as those of Weisbach, Leopold Glück, etc.) at the service his own theoretical speculations.

Bulgarian anthropology appears to have been committed to the earlier German anthropological tradition that Benoit Massin has called "racial liberalism," associated with inductive data-gathering and anthropometrics. In Bulgaria, this influence expressed itself in anthropologists' relatively high

80 Niko Zoupanitch, Ave Illyria (Paris: Société Générale d'Imprimerie et d'Édition Levé, 1919), 46.

81 Ibid.

82 Ibid., 46-47.

83 Ibid., 51. 
professional standing and their large-scale studies of recruits and schoolchildren. Lacking the resources of the Bulgarians, Županić concentrated instead on racial theories, which had already entered the German anthropological mainstream. His variations on Aryanism may also be traced to his interest in prehistory and linguistics, where speculative theories had traditionally played a larger role than in the narrower field of anthropology.

At least since the Enlightenment, the population of the Balkan Peninsula had been considered inferior, backward, and uncivilized. Such attitudes brought native anthropologists into a precarious position: Even in anthropology's "liberal" variant, they applied knowledge laced with intrinsic hierarchies that differentiated between a European "us" and a non-European "them." The Balkans were neither self nor Other; with their postcolonial setting following the end of Ottoman rule, they ranked somewhere "betwixt and between." Consequently, native anthropologists adopted epistemes from European anthropology as long as they were not in direct contradiction with their own national codes. Where contradictions occurred, they sought refuge in "nesting orientalisms," as Vatev's rebuttal of Deniker's amalgamation of Christian Bulgarians with Muslim Turks showed. Županić, on the other hand, gratefully appropriated Deniker's concept of the Adriatic/Dinaric race, hoping it would push the association of brachycephaly with racial inferiority into the background. He further tried to harmonize long heads with short by praising the advantages of racial mixture and diversity. But through the back door, he reaffirmed the hierarchy by pleading that the South Slavs had once had the appearance of the Nordic race and had lost it due to an unlucky combination of circumstances. Like Vatev, Županić was a "mimic man"-like a colonizer, but different ${ }^{84}$ - who could reproduce Western orientalisms on a smaller scale, to some degree vis-àvis Greeks and Bulgarians, but primarily vis-à-vis Albanians and Turks.

In both the Bulgarian and Serbian examples, we see attempts to formulate a canon of somatic traits typical for each nation, whose geographical distribution could be used to justify territorial pretensions. While Županić went to great lengths with his theory about the anthropological unity of the South Slavs, his Bulgarian colleagues, after initial optimism, refrained from such endeavors. In this context, it is intriguing that, although there were attempts to assess the affiliation of the Slavic population of Macedonia, the issue never played the preeminent role one might expect, given the pivotal place of the Macedonian question in the Balkan Wars and World War I.

While anthropological theories were enlisted to support military goals, the war years-in the Balkans from 1912 to 1918-offered the chance to study recruits and POWs. Županićs studies of POWs in the Balkan Wars may have

84 Maria do Mar Castro Varela and Nikita Dhawan, Postkoloniale Theorie: Eine kritische Einführung (Bielefeld: transcript, 2005), 90. 
been the first on European soil, but, due to the larger conflict that ensued, his dubious claim to fame did not gain international attention. The garrisons and POW camps of the Great War were not focal points for Balkan anthropologists; more often, they were focal points for typhus. One outbreak originating in a camp filled with Austrian POWs killed up to 150,000 people in Serbia in the spring of $1915 .{ }^{85}$ Despite Birkner's approving assessment of Bulgarian anthropology, the role of the Great War in its development should not be overestimated. After all, it took until 1918 for Drončilov to obtain permission to conduct his examinations of native populations in Kosovo and Macedonia.

For Županić, the peace negotiations after the war provided a forum for the dissemination of racial theories. But such anthropological argumentation was of use only to propagandists: Where scholars were invited to participate in drawing new maps, census data and ethnographic argumentation were considered more persuasive than the shapes of skulls. ${ }^{86}$

The end of the war ended an era in Balkan anthropology. The caesura was both biographical and methodological. Drončilov, who had a teaching position in geography and ethnography at the University of Sofia, died in an accident in 1925. ${ }^{87}$ Županić returned to Belgrade only briefly before moving to Ljubljana to become director of its newly founded ethnographic museum. Still in Ljubljana in 1940, he became a professor of ethnology at the age of sixty-one. ${ }^{88}$ A new generation of professionals-Božo Škerlj in Ljubljana, Boris Zarnik in Zagreb, and Branimir Maleš in Belgrade, to name the most important-became active in the second half of the 1920s in Yugoslavia. They were biological anthropologists and advocates of eugenics, and, from 1941 to 1945, with the exception of Škerlj who survived imprisonment in Dachau, they supported the quisling regimes. ${ }^{89}$ In Bulgaria, a school associated with the biologist Metodij Popov

85 Richard Pearson Strong et. al., Typhus Fever with Particular Reference to the Serbian Epidemic (Cambridge, MA: Harvard University Press, 1920); William Hunter, "The Serbian Epidemics of Typhus and Relapsing Fever in 1915: Their Origin, Course and Preventive Measures Employed for their Arrest," Proceedings of the Royal Society of Medicine 13, no. 2, Section of Epidemiology and State Medicine (1919): 29-158.

86 Andrej Mitrović, Jugoslavija na konferenciji mira 1919-1920 [Yugoslavia at the peace conference 1919-1920] (Belgrade: Zavod za izdavanje udžbenika SR Srbije [Institute for the Edition of Textbooks of the Socialist Republic of Serbia], 1969).

87 Анастас Иширков [Anastas Iširkov], "Д-р. Крум Дрончилов" [D-r. Krum Drončilov], Общ годишник за България (1926-1929) [General Yearbook for Bulgaria (1926-1929)] 3 (Sofia: Дружество на столичните журналисти [Society of the Capital's Journalists], 1928): 600-602.

88 Promitzer, "Niko Županič and the Issue of Yugoslavism," 19-20, 28.

89 Christian Promitzer, "Vermessene Körper: 'Rassenkundliche' Grenzziehungen im südöstlichen Europa," in Europa und die Grenzen im Kopf, eds. Karl Kaser, 
(1881-1954), which combined anthropometrics with blood-group analysis, came to power between the wars. Popov's magnum opus on the anthropology of the Bulgarians was published posthumously in 1959. ${ }^{90}$

One question remains to be answered: Why did Bulgarian anthropology before 1912 receive support from the state, the church, and the army, while Serbian anthropology in the same period remained virtually the private domain of a Slovene émigré historian? The one person who could have given Serbian anthropology a similar momentum was the geographer Cvijić, but his school of anthropogeography was more interested in ethnology than in taking anthropological measurements. The reason for his success, in turn, may have to be sought in the intrinsic logic of nationalism and nation-building: When the Serbian principality was founded in the early nineteenth century, nationalism played a secondary role. The self-image of Serbia as the nation-state of the Serbs only became important in the 1840 s. Since this period, national programs had been developed to address the issue of real and virtual, concentrated and scattered Serbian communities located in Hungary, Croatia, Dalmatia, BosniaHerzegovina, Montenegro, and the European provinces of the Ottoman Empire (Kosovo, Macedonia, and Albania). The diaspora was-as it still is-the central issue in Serbian nationalism. Anthropogeography fit that scheme perfectly, since it concentrated on ethnographic study and the historical reasons for migration. State resources were thus diverted away from physical anthropology.

Bulgaria, on the other hand, had established itself as a nation-state with its founding in 1878. But the move came late: Serbia, Romania, and Greece had already taken up positions in the neighborhood. Being latecomers, Bulgarian intellectuals felt uneasy about the rootedness of their nation; consequently, they were deeply committed to discussions about the origin of their nation, which was Slavic by language, but had a non-Slavic name. Oscillation between Slavism and its opposite became one of the leitmotifs of the modern Bulgarian self-image. They had to position their nation not only vis-à-vis the neighbors, but also vis-à-vis other Slavic nations-in particular the Serbs, but also Russia, with whom relations were volatile. Physical anthropology had an important role to play. How well it succeeded can be seen in Birkner's compliment that Bulgarian physical anthropology "has been hardly equalled, and never surpassed anywhere."91

Dagmar Gramshammer-Hohl, and Robert Pichler (Klagenfurt: Wieser, 2003), 384-387.

90 Методий Попов [Metodij Popov], Антропология на българския народ. 1. Физически облик на българите [Anthropology of the Bulgarian people: I. Physical shape of the Bulgarians] (Sofia: БAH [Bulgarian Academy of Sciences], 1959).

91 Birkner, "Die anthropologische Erforschung Bulgariens." 